Olha SAZONETS, Zoriana VALIULLINA

\title{
AEROCOSMIC BRANCHES IN SYSTEM OF WORLD AND UKRAINIAN MILITARY ECONOMICS
}

\begin{abstract}
Two scientific methodical approaches are singled out to research military economics: as a constituent part of military business which provides for the defence (military) potential of the state, and as a science which studies regularities of economic provision for military business in the state (defence, building, maintenance of armed forces, etc.). It is to be noted out that the competition at the world market of weapons takes place mainly between the USA, Russia, Germany, China and France, the share of which constitutes $74 \%$ of military production export.

Within the framework of researching military economics are singled out branches manufacturing planes-fighters and production for cosmic sphere. Advantages were shown of planes-fighters of the fifth generation of the USA F-22, F-22 and F-35 Lightning 11 (project is financed by the USA together with Italy, the Netherlands, Australia, Canada, Turkey, Norway and Denmark) over Russian-Indian project T-50 and Chinese Chengdu J-20 and J-31. The evaluation is

(C) Olha Sazonets, Zoriana Valiullina, 2017.

Sazonets Olha, Dr. of Econ. Sciences, Professor, National University of Water Management and Nature Resources Use, Rivne, Ukraine.

Valiullina Zoryana, Cand. of Econ. Sciences, Associate Professor, National University of Water Management and Nature Resources Use, Rivne, Ukraine.
\end{abstract}


made that leading countries are able by 2030 to build planes-fighters of the sixth generation.

The opinion is expressed that the geopolitical position of Ukraine and, in particular, the aggression and annexation of Crimea by Russia make a priority of restoring the fighting capability of the military aviation of Ukraine and of increasing the level of its combat power. It is stressed that for this purpose it is necessary to systematically and rather rapidly substitute the Soviet-Russian aviation technology for American one. The possible ways for equipping armed forces of Ukraine with new planes-fighters are determined the following: their development and manufacture in cooperation with other countries or the organization of licensed manufacturing, import, rent or lease of present-day fighting planes of foreign make.

Taking into account that Ukraine enters the club of cosmic states and through the lacking finances it at present is unable to compete on equal terms in manufacturing aerocosmic technology it is suggested to re-orient the economic policy of the country at integrating into European cosmic branch. It is pointed out that for this purpose it is necessary to load the capacities of the State enterprise «Production association «Southern machine building plant named after O.M.Makarov» and designing bureau «Pivdenne». It is recommended to develop the cooperation of Ukraine in manufacturing rocket-carriers «Zenith» for projects «Sea start» and «Land start» and the cooperation with American companies (Orbital ATK - RH «Antares») and European (AVIO, Italy - PH «Vega»); to implement ambitious Ukrainian-Brazilian project «Cyclone-4». It is made more precise that Ukraine may propose to partners the cooperation in continuing the development of multifunctional rocket operative- tactical complex «Sapsan».

\section{Key words:}

Military production, aviation building, cosmic branch, development, world market.

JEL: D74, D78, E22, E23, L80, L93, F02, O32, O33, O38. 


\section{Introduction}

Problem setting. At a new stage of global processes of mankind development and transformation of world economics a substantial place is devoted to the implementation of the paradigm of high technological development of national economies. The development of high technological branches of economics in world countries is becoming decisive for the intensive type of economic reproduction because the transfer to manufacturing highly technological production is accompanied by decreasing materials- and power capacities of production, by increasing labour productivity and, correspondingly, by growing the competitiveness of a country. At present indisputable is the fact that highly technological production is the main factor to increase population employment and the level of wages which, in its turn, is stipulated by the intensive growth of world production and volumes of exporting highly technological production [1, p. 39-45].

The development of innovation processes, the manufacture of highly technological production are connected with one more advantage the influence of which is not to be underestimated, - military security. In the process of implementing integration processes for our country an urgent necessity arose of creating its own model of developing the defence potential, in particular, on the basis of speeding up the development of aerocosmic branch. Present-day geopolitical conditions stipulate the necessity of transforming the Ukrainian defence industrial complex which is possible only on the basis of comprehensive utilization of all fundamental factors of scientific technical progress.

Analysis of studies and publications. Ukrainian economists: T.M. Velenteychyk (Popovych, Velenteichyk, 2010), O.V. Dehtyarev (Dehtyarev, 2013), V.P. Gorbulin (Gorbulin, 2015), I.L. Sazonets (Sazonets, 2016), I.G. Khanin (Khanin, 2015), and A.I. Kharuk (Kharuk, 2008) devoted their works to study the development of military branches of industry in Ukraine. Urgent issues of economic policy of the state in scientific technological sphere are stated in works by T.V. Grinko, T.S. Orlova (Orlova, 2011), O.V. Kamyanetska (Kamyanetska, 2015) and a number of other native experts. However, notwithstanding the availability of rather substantial developments of this theme, deeper research requires the generalization of world experience in using the production of highly technological branches in developing the defence potential, in particular, on account of aerocosmic branch.

The objective of the article is to research theoretical principles and applied problems in functioning of the world market of aerocosmic production, to generalize world experience in developing aerocosmic branch as a factor of de- 
fence capability and to determine ways of strengthening competitive positions of Ukraine at the market of aerocosmic production.

\section{Theoretical constituent parts of military economics}

With the aim of carrying out the research it is necessary to define notional categorical apparatus. Under military production authors usually understand weapons, military equipment, military machinery and other property, scientific technical and other production, and also works implemented in defence interests. Military production is developed, manufactured, maintained, utilized and buried in correspondence with obligatory requirements in the branch of technical regulation established by state consumers of defence demand and authorized by organs of executive power.

The sphere of using military production is determined by its specific purpose. Military production is supplied by state defence demand of production (works, services) which are used with the aim of defending the information which is the state secret or belongs to defended one in correspondence with the legislation of Ukraine, of other information of limited admission, production (works, services), data about which are state secret, and also processes of designing (including prospecting), the production, construction, assemblage, maintenance, storage, transportation, realization, utilization and the burial of the said production.

Military production is used only in military economics. Military economics may be treated from two scientific methodical approaches. Firstly, under military economics it is necessary to understand one of the most important and developed branches of state economics which in broader understanding embraces all economic issues of military business, provides for the defence (military) potential of the state. Secondly, it is a science which studies regularities of the economic provision for military business in a state (defence, building, maintenance of armed forces, etc.).

Let us consider in more details the first approach. The development of military economics is inseparably connected with the general development of the economic potential of the state, its possibility concerning its functioning under conditions of military actions (war) and meeting the needs of armed forces during war and peaceful period.

The development of military economics envisages the creation of mighty branches of defence (war) industry, the growth of their production capabilities, the corresponding geographic deployment of defence (war) enterprises on the 
territory of the state, the establishment between them of stable economic and scientific technical ties, the mastering of new technologies, the preparation of power engineering, the development of agriculture, health protection, the network of state communication, transport network taking into account the provision of operations, the implementation of defence measures concerning civil defence.

It is worth mentioning that military economics is not singled out from civil one - the whole number of branches and enterprises manufacture both civil and military production or manufacture production which is consumed both in civil and in military sectors of economics (production of double designation) (footwear, clothes, textiles, foodstuff, transport, etc.).

From the point of view of the second approach military economics - is a constituent part of military science. It studies interrelations between military (combat) actions (armed conflicts, war) and economics, questions of evaluating and comparing military economic potentials of opposing states (coalitions of states), the determination of forms and ways of mobilization preparedness of economics (national economy) and its transfer into martial law in case of necessity, the provision for the efficiency of the system of functioning military economics and the use of resources directed at military purposes, etc.

Military economics as a science is the system of knowledge about economic processes and phenomena taking place in various spheres of the state defence activity. In this meaning military economics is closely connected with economic and military science. Economic basics are the main object of research for military economics:

- guarantee for defence and security of state (country);

- guarantee for military economic potential of state (country);

- guarantee for mobilization preparedness of economics (national economy) of state (country);

- guarantee to implement military duty and military service;

- guarantee cooperation in military sphere;

- interrelation between war (armed conflicts) and economics.

Thus, it is possible to draw a conclusion that military economics both as an objective reality and as a science develops under specific conditions. The specifics lies in the fact that military economics is, on the one hand, a part of national economy with its specific regulated market relations via demand and supply. On the other hand, it services the military organization of the state with its centralized management and high responsibility for final results of functioning - guaranteed military security of state. 


\section{Competition at the world market of production of military designation}

With the aim of defining competitive advantages of high technological branches of military economics of Ukraine it is expedient to analyze the presentday state of the world system of the provision with the production of military designation.

The world market of weapons and military equipment being one of the most large-scale and simultaneously rather specific and much politicized market had undergone substantial transformations at the end of the 20th century. The main moving force in its formation gradually becomes traditional economic factors based on categories of demand-proposal and world prices. At the world market of weapons and military equipment there began to appear principally new tendencies, substantially changed the character of competition, forms and methods of trade, the role had transformed of international and national regulation of this business sphere.

By estimates of the Stockholm institute researching world problems (SIPRI), one of the most authoritative organizations in the world in issues of the control over weapons, the amount of legal international trade by weapons exceeds 40 billion dol. per year. The largest exporters of weapons in the world in 2010-2014 had been the USA, Russia, Germany, China and France: their share constitutes $74 \%$ of world export if military production. Here the USA and Russia have, unconvincingly, the largest shares - correspondingly $29 \%$ and $27 \%$, that is, more than half of the total world export of weapons (fig. 1).

Main importers at the world market of military production in recent years had been India, China, Pakistan, UAE and Saudi Arabia. These countries in the period from 2010 to 2014 have $32 \%$ of the whole import of weapons.

In the world defence industry during recent 30 years there were observed significant transformations. They are stipulated by the orientation at winning and keeping technological leadership by enterprises. As national security permanently remains as the most important state priorities military sphere is paid the foremost attention, and hence, innovation breakthroughs here are a priori obligatory. Traditionally most of innovations are introduced in the military sector of aviation building; therefore, it remains without doubt the moving force of developing the whole military branch. Accumulated potential of developments in military aviation building stipulated a new source of its development. One of the dominant trends lies in the fact that fighters take the forward place in the development of military production. 


\section{Figure 1}

Leaders of world market of export of military production

(http://razumkov.org.ua/ua/novyny-tsentru/prezentatsiia-shchorichnyka-sipri2015-ozbroiennia-rozzbroiennia-ta-mizhnarodna-bezpeka)

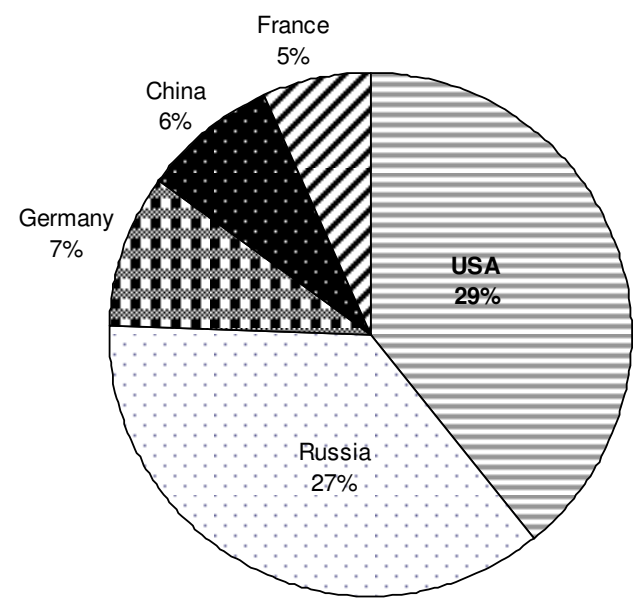

Figure 2

The movement of export and import of military production in the world (http://www.aif.ru/infographic/1137465)

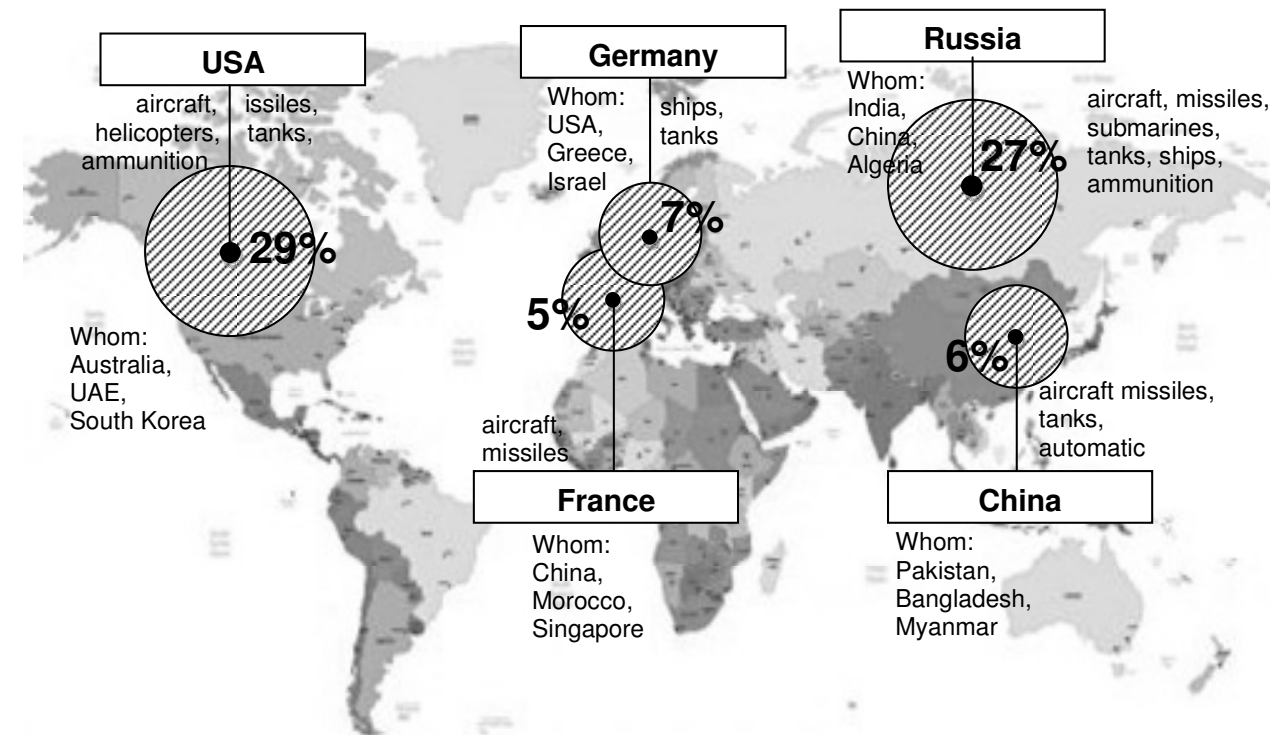




\section{International competition of market proposals for combat airplanes-fighters}

Since the First World War military combat aviation made a qualitative breakthrough in development. The present-day fighter is a rather universal airplane-fighter designated for destroying the enemy aviation, destroying ground and sea aims. Besides, extremely important role it plays for air surveillance. In present conditions the main designation of airplanes-fighters remains the carrying out of air combats. Fighters of the last generations represent themselves as supersonic jet airplanes capable of carrying hundreds of kilograms of bombs and rockets.

Let us consider the type of combat planes-fighters which at present belong to the fifth generation. The first plane-fighter of the fifth generation which had been taken as a weapon in the USA was F-22 Raptor manufactured by the American firm «Lockheed Martin». It is to be pointed out that the implementation of the program to create F-22 began as long ago as in 1983, however, the first flight had been carried out on 19 November 1990, and in 11 years the serial production of F-22 began From December 2005 the fighter had been put into service in MAS of the USA. We consider that the plane-fighter of the fifth generation F-22 was built using «stealth» technologies due to which it has small radiolocation observation.

It is worth mentioning that at present F-22 Raptor is the only in the world fighter of the fifth generation which had been put into service. The more so, by official data, the stealth technology used in it by far surpasses analogous technologies in all planes-fighters of the fifth generation. It is important to point out that F22 is the most expensive plane-fighter during all history. By data of main controlling office (GAO) of the USA by the end of 2010the complete price of a plane F22 (taking into account the cost of development program) achieved 4117000000 doll.

Notwithstanding the fact that F-22 had been being developed as long as the end of the $20^{\text {th }}$ century, with its technical characteristics hardly can be compared planes developed after 2000s. With the wing spread of 13,56 metres (wing square -78 sq.m), the length of $18,92 \mathrm{~m}$ and the height of 5 meters the plane may carry more than a ton of various weapons including the built-in $20-\mathrm{mm}$ gun M61A2 Vulcan with 480 cartridges and rockets or bombs depending on the task carried out Two turbojet engines Pratt Whitney F119-PW-100 supply the plane with the supersonic cruiser speed of $1200 \mathrm{~km} / \mathrm{h}$ and $2800 \mathrm{~km} / \mathrm{h}$ in the boost regime. The practical ceiling of the plane is 20000 metres, and the great supply of 
fuel guaranteed the flight distance of $3000 \mathrm{~km}$ (http://www.gumer.info/ bibliotek_Buks/Econom/world_econom/20.php ).

The USA - the only country in the world in which at present there are fighters of the fifth generation F-22 Raptor numbering195 pieces. However, because of the tremendous cost (up to $140 \mathrm{mln}$. US dollars a piece) their production had been closed down for a time. In connection with this the USA are working to develop more technological and at the same time a cheaper variant.

Another plane of a similar class is the airplane-fighter of Russian-Indian project T-50. Military air forces of the Soviet Union prepared requirements for the fighter of the fifth generation at the end of the 1980s. On the basis of these requirements RPC «MiG» developed the project Mikoyan 1.44, and Sukhiy DB Su-47. However, to continue the work over the fighter of the fifth generation it was unable, because this period coincided with the disintegration of the Soviet Union. And. Correspondingly. Financing had ceased. Only in 2002 the work on a new plane was resumed by Sukhiy DB, and the basis of a new plane comprised some technologies of Su-47 and MiG 1.44.

A new Russian fighter had obtained the name of T-50. However, the world heard about it only in three years. T-50 had its first flight on 29 January 2010, but for the present time the plane continues to have flight tests, and the serial manufacture of the fighter has not yet begun. The interesting fact is that because of the lack of financing Russia had to develop the plane-fighter of the fifth generation jointly with India, and hence, it will be put into service as minimum in two countries.

The comparison of technical characteristics shows that $\mathrm{T}-50$ is very near to American F-22. It was performed by the same aerodynamic scheme and has approximately the same dimensions (length -20 metres, wings spread -14 metres and height $-4,8$ metres). In contrast to its American analogue, the Russian fighter has somewhat less maximum speed - only $2600 \mathrm{~km} / \mathrm{h}$, but with all this it has by far greater flight distance $-5500 \mathrm{~km}$ (http://info-svit.org.ua/2013/07/honkaozbrojen-litaky-vynyschuvachi-pyatoho-pokolinnya/).

Another known all over the world became the Chinese multi-purpose plane-fighter Chengdu J-20 which had made the first test flight in 2011. At first a new plane had to belong to the generation 4+, but in 2010 it became known that the plane will meet all requirements for the fighter of the fifth generation. So far information about the new fighter is not yet much, but it has already became known that it will be able to develop supersonic speed without using the boost, is able to maneuver with great overloads, is equipped with electronics, is little noticeable and multi-functional, with the possibility of a short take-off (http://infosvit.org.ua/2013/07/honka-ozbrojen-litaky-vynyschuvachi-pyatoho-pokolinnya/ ).

In contrast to Russian T-50 and American F-22, Chinese J-20 is a comparatively big tactical combat plane of aero dynamic scheme «rolling» with a big 
delta-like wing and a completely turning horizontal empennage. Probably, the plane length is about 21-25 metres, the wing spread - 13-15 metres, and the maximum speed is at the level of $1900-2300 \mathrm{~km} / \mathrm{h}$. [12]. The fighter is to be put into serial production, by preliminary data, in 2017-2019. Now China is conducting the development of one more fighter of the fifth generation - J-31.

However, the USA have one more development in the sphere of military plane building - a fighter F-35 Lightning II. The plane F-35 was built due to the program JSF (Joint Strike Fighter). F-35 Lightning II was developed by the company «Lockheed Martin Aeronautic Company» which became the winner of JSF. The first flight had been on 15 December 2006. The financing of the project is being done not only by the USA but also by Italy, the Netherlands, Australia, Canada, Turkey, Norway and Denmark ((http://www.gumer.info/bibliotek_Buks/ Econom/world_econom/20.php ).

F-35 Lightning II - is a perspective barely visible fighter-bomber of the fifth generation developed by the American firm «Lockheed Martin Aeronautics Company» (Tactical Aircraft Systems)» in three variants: to provide for Military Air Forces of the USA (ground fighter CTOL), for Corps of Sea Marines of the USA and for Military Sea Forces of Great Britain ( a fighter with a shortened take-off and a vertical landing: STOVL) and also for Military Sea Forces of the USA (a Carrier-based fighter: $\mathrm{CV}$ ).

It is worth pointing out that $\mathrm{F}-35$ was being developed after its predecessor $\mathrm{F}-22$, and in the process of its development many similar technologies were used. Maybe, this is why the plane, however, became not so advanced. Because of the need of the vertical take-off and landing the plane had to use only one jet engine, and this, in its turn, led to the fact that the cruiser speed of F-35 was only $850 \mathrm{~km} / \mathrm{h}$, that is, is pre-sonic. It was because of this many critics consider this plane to be not of the fifth but of the 4++ generation. However, considering the fact that in the boost regime the plane may develop the speed of $1900 \mathrm{~km} / \mathrm{h}$, and that all other characteristics meet the requirements of the most up-to-date fighter, it is adopted to consider F-35 to be an aircraft of the fifth generation. Besides, it is to be made clearer that in contrast to F-22 F-35 is designed not only for the USA. The unified model of the fighter-bomber is designated to be supplied to NATO countries. At present F-35 is put into service for the USA, the Netherlands, Australia, Great Britain, Japan, Italy and Israel.

The only striking fighter F-35 of the company «Lockheed Martin» is to become the basis of the park of tactical fighters of the USA. However, by far not every country in the world may permit itself to use expensive fighters of the fifth generation.

Thus, it is possible to state that a leader in manufacturing aircraft-fighters of the fifth generation is the USA. Besides, the fifth generation of aircrafts is developed by not so many countries. However, countries-leaders in the world at present are already working at fighters of the sixth generation. 
In the UAC (Unified aviation Building Corporation) it is believed that the prototype of the fighter of the sixth generation may make its first flight in 20232025. About the complete readiness it is possible to speak after 2030 (http://army-news.ru/2016/07/istrebitel-6-pokoleniya-zavtra-dlya-rossii-i-ssha/ ). A new fighter will have two variants - with a pilot and without him. It is the pilotless variant that makes it a terrible and mighty weapon. The absence of a man in the cabin, besides saving the place and weight, will give the possibility to do maneuvers which a human being will not endure physically. Taking into account the development of computer technologies it is to be surely said that in the 30s of the $20^{\text {th }}$ century this aircraft will be not only be radio operated but also will have the complicated and clever program that will help control it and in case of breaking the communication will take for itself all the functions of controlling (http://blogs.korrespondent.net/blog/users/3223445-ameryka-prezentuvalavynyschuvach-shostoho-pokolinnia ).

The variant with a pilot will have rather other peculiarities. In general, the maximum efficient action of aircrafts - is a collective one. In other words, one or two pilots on planes of the first modification will serve as a commanding centre for 2-4 pilotless fighters. Approximately in this way may act MiG-31 BM for other planes (http://army-news.ru/2016/07/istrebitel-6-pokoleniya-zavtra-dlya-rossii-i-ssha/).

\section{Formation of aviation branch on terrains of Ukraine $\left(20^{\text {th }}\right.$ century)}

Revolutionary changes at the world market will incite manufacturers in Ukraine to develop and produce present-day types of weapons. This meets new tendencies to increase military power in many countries of the world, to intensify the military potential of countries-leaders in manufacturing weapons and enlarging the import of weapons among countries-consumers. Ukraine having mighty military industrial base, notwithstanding internal requirements in weapons still remains in leaders among countries-exporters of weapons (Kamjanetska, 2015). Ukraine has the experience in manufacturing aircrafts-fighters, however, it was used only in the first half of the $20^{\text {th }}$ century. Besides, this type of military production did not play the main role in Ukrainian aviation industry.

One of the firms attracted to produce fighters had been the Odessa «Anatra». Here under the guidance of a French engineer Dekan in 1916 had been designed a single-seater fighter-monoplane «Anamon» («Anatra Monokok'). The plane was equipped with the engine «Gnome-Monosupap» with the capacity of 100 h.p. and was armed with a machine-gun. In June 1916 «Anamon» in general had passed successfully factory tests developing the maximum speed of 165 $\mathrm{km} / \mathrm{h}$. This gave the basis to consider «Anamon» as a prototype for planned at 
«Anatra» for serial manufacture in the beginning of 1917 of 100 fighters (Kharuk, p. 154).

Their serial production was being prepared at a new plant of the firm in Simferopol. The contract for supplying during April-June 1917 hundred fighters «Newpor XVII» was drawn on 30 January 1917 but its implementation was being hindered because of the absence of engines. Only at the end of September «by external inspection» (that is, without carrying out flight tests) military officials had adopted first 50 "Newpors», and at the end of February of 1918 - the rest. Further on a part of plains remaining in Simferopol were for all that equipped with engines as from January 1919 at least ten «Newpors» with «Anatra» series numbers had appeared in registers of the aviation of Volunteer army (Kharuk, p. 31-32).

Attention is to be also paid to one more fighter "Anatra» - the plane «Anadis» designed on the basis of the reconnaissance aircraft «Anasal» with the powerful engine «Ispano-Siuza». An experimental model of this plane at the end of 1916 - the beginning of 1917 had been passing tests, but because of the absence of engines it was not built serially (Kondratjev, p. 16).

Into the plan for plant No 135 there were introduced 80 new fighters. However, the introduction of I-Z was being hindered: working drawings and a ready plane as a sample came from plant No 39 only in March 1934. The supply to the client of fighters produced in Kharkov began only at the end of August. However, the plan for 1934 had $30 \mathrm{I}-Z$ included but really the manufacture of this consignment had been completed only by April 1935 . Another 30 planes were put into service to the client at the end of 1935 (Maslov, p. 7).

Taking into consideration the above mentioned reasons the testing of the second prototype began only at the end of October 1940 and was completed on 5 January 1941 and about the output of the consignment of 10 planes there could be no word. The situation about the plane had become critical after on 14 January the prototype Ta-1 crushed in performing the controlling flight because of the failure of one of engines. Trying to save his "creation» Tairov had addressed a letter to the Chairman of Council of people's commissars) (CPC) V. Molotov suggesting to build immediately 161 small consignment (15-20 planes) to carry out urgent state and military tests. The reaction to Tairov's letter was quick. Already on 25 January 1941 a joint decree was issued of CPC of the USSR and CC of VKP (b) No 197-96 by which V. Tairov had been assigned to build and present for state testing two improved planes Ta-3 with new engines. The first of them (with M-89 engines) had to be ready by 1 May 1941, and the second (with M-90 engines) - by 1 October of the same year. The second plane had to take also strengthened weapon - two 23-mm guns MP-6 and one 37-mm ШФЛ-37 (Medved, p.30).

On 14 December 1940 an order was issued about the introduction into production at the plant No 165 of the fighter ЛаГГ-3 which had the wooden con- 
struction. In correspondence with this order plants No 21 and 23 which earlier began to organize the production of such planes had to render the technical assistance to Dnipropetrivsk enterprise. It was envisaged in the second quarter of 1941 to manufacture in Dniropetrivsk 40 planes ЛаГГ-3 and the annual plan for 1941 was 250 planes. However, before the beginning of Soviet-German War the production of fighters at the plant No 165 had not yet been possible to arrange (Kharuk, electronic resource).

A new stage in the development of aviation building is signified by the use of new technologies under conditions of limited financial possibilities. In 1992 in Ukraine there were 2800 flight apparatuses of different class and designation. In 22 years at the moment of the beginning of Russian aggression against Ukraine the park of military aviation of Air Forces had about 170 combat planes (bombers, attack aircrafts and fighters) and battleworthy among them were considered to be not more than 40 pieces.

\section{Development of aviation branch in military economics of Ukraine}

The development of present-day aviation machinery is an extremely complicated process which requires substantial time expenditures, material and human resources. Today in leading countries of the world the development of perspective planes of combat aviation is concentrated predominantly on creating multifunctional machines (combat aircrafts of the fifth generation), capable to carry out various tasks: reconnaissance, aim indication, strikes inflicting, carrying out air combats, suppression of radio-electronic means, breakthrough of antiaircraft defence (https://www.nasa.gov/sites/default/files/atoms/files/asap_2015_ annual_report.pdf ).

Many military specialists and experts do not doubt that among other tasks and objectives of Armed Forces of Ukraine one of priorities is the restoration of combat capability of military aviation and strengthening the level of its combat power. Without doubt, without the proper technical equipment and corresponding strengthening of the park of combat aviation equipment (not speaking about its equipment with new samples) to do this will be impossible. Also, without increasing the intensiveness of training and preparation (mostly on practical level) of flight and technical staff of aviation units and subdivisions of Air Forces of Ukraine (http://na.mil.gov.ua/32104-krila-majbutnogo-abo-pro-perspektivi-texnichnogopereosnashhennya-ukrayinskoyi-vijskovoyi-aviaciyi ).

Hence, it became clear that for Ukraine to "take another seat» from Soviet (Russian) combat aviation to American one it is necessary first to train pilots and servicing personnel. Really there is nothing new here. Approximately the same 
road had been taken by Air Forces of Israel which earlier had used Soviet МіГ29, but later transferred to more efficient F-15 and F-15 and at present they have one of the most powerful aviations in the world.

Thus, at present the military aviation of Ukraine is in need of systemic technological renovation, in particular, rather rapid and significant. The introduction of new technologies in Ukraine envisages the obligatory cooperation of native scientific, production, military and civil organizations with foreign ones. Possible ways of equipping Armed Forces of Ukraine with new planes-fighters are: the development and production of planes-fighters the purchase (rent)or leasing of modern combat planes of foreign make.

The creation of factually new Ukrainian planes within the framework of modernization of well known in the army types and models of aviation equipment still of Soviet development and manufacture became a reality. The Ukrainian specialists of aviation repair sphere of native DIC had already created a number of renovated and modernized planes, for example, Су-25М1, Су-25УБМ1, МіГ$29 \mathrm{MY} 1$ and $Л-39 M 1$.

However, it is to be pointed out at once that any of the variants concerning the purchase of planes requires the substantial rebuilding both of maintenance and repair-servicing infrastructure of the country (beginning from the arrangement of aerodromes and finishing with servicing new planes). Not speaking yet about the necessity of introducing rather substantial changes into the program and content of training flight-takeoff and technical composition of aviation units and subdivisions, and also of military educational institutions.

From results of research carried out it follows that at present the perspective guideline for the development of Ukrainian military aviation is the provision of technical equipment not only in respective military structures but also at the state level.

\section{Aerocosmic branch: competition and integration processes}

\subsection{Leadership of the USA in aerocosmic branch}

By higher level of military potential and perspective development both in military sphere and in continuing the existence of mankind in general is marked the cosmic branch. At present military economics uses the experience of cosmic branch the leader of which is NASA (National Aeronautics and Space Administration). It had been founded by the government of the USA in 1958 for researches 
in the branch of aeronautics and space flights. The headquarters of NASA are situated in Washington; the main starting site - at the cape of Canaveral in the Kennedy Cosmic centre in Florida. The first space program by NASA had started with launching the cosmic apparatus «Pioneer» in 1958 which collected the information for further piloted flights the best known of which had become the flight to the Moon of «Apollo-11» on 16-24 July 1969.

NASA had been set up by way of reorganizing the American National Advisory Committee for Aeronautics or NASA which from 1946 was engaged in studying rocket construction and developed the first in the world a supersonic plane Bell X-1. From the beginning of the 1950s this agency had transferred to developing artificial Earth satellites and projects the implementation of which would give the possibility to carry out their successful launch into the Earth orbit. The main competitor of the USA in mastering the cosmic space had become the USSR the space program of which had been developing by swift tempos. At the beginning of cosmic era the issue of studying space came from the essence of research sphere and played a tremendous role in mutual relations of two world superpowers and in guaranteeing the balance of force between them.

One of the advanced programs of NASA had been Space Transportation System, more known as a Space-shuttle (from English Space shuttle - cosmic shuttle). - an American reiterative transport cosmic ship. The shuttle was launched into space with the help of its own rocket engines and hard-fuel boosters, fulfilled maneuvers at the orbit as a cosmic ship and returned to the Earth as a plane. It was planned that shuttles will fly like ships between circum-terrestrial orbit and the Earth sending useful loads in both directions. During developments it was envisaged that each shuttle had to start into space up to 100 times. In practice there were performed only 135 launches. Before March 2011 most flights - 39 had been carried out by a shuttle «Discovery». In the process of the program in catastrophes 3 ships crushed with 14 astronauts (https://en.wikipedia.org/wiki/NASA. ).

One of the main directions of mastering cosmic space at present - is the creation and functioning of the International space station (ISS) which is the largest object which people at any time launched into orbit. Regretfully, one day it will become one of the largest objects which will be falling down from orbit, or it at the end of its term of useful utilization, or with little truth there may become its catastrophic destruction. During last 3 years NASA and its international partners achieved substantial progress in developing the plan how to safeguard the safe descent from the orbit of ISS at any time. Now they are in the final stage of developing these projects. In case of a serious failure the possibility of non-planned emergency descent by ISS exists. Because of this NASA and its international partners are recommended to complete the planning and preparation necessary to be ready for such an event. 
Recently there had taken a significant improvement in openness and transparency of CCP (Commercial Crew Program) - a multistage NASA program in developing private piloted space ships for dispatching astronauts to the International space station. In particular, highly are evaluated the efforts of CCP- a dispatcher of the programs in this branch, and also its support on the part of the higher management of NASA. Now there takes place the concentration at specific problems of NASA. Beside this, CCP continues to balance between guaranteeing the responsibility of NASA for the crew safety and the permission of commercial suppliers for further solution of its tasks. The success of the mission is guaranteed with the refusal of excessive restriction concerning these solutions.

The attention is to be paid to the fact that the budget of NASA is insufficient to implement all current obligations with a minimum proper risk. The program risk may lead to compromised solutions which are incompatible with safety practice. Historically it had become that the most successful programs reflect the deviation into the safety side, earlier financing for supporting major design and system decisions. The volume of available resources and the distribution of time when costs become available is the question for working out Exploration Systems Development (ESD) and also the crew of the program of CCP. The annual budget request of the USA President concerning CCP and its implementation is shown in fig. 3.

CCP had been underfinanced in critical first years of development. In particular, the Program obtained only $57 \%$ of requested financing in financial 2011 2013. Financing has to be added, as is stated by specialists, for managing the program in safety problems. Also there is a high risk of the program not to be able to get sufficient financing to implement planned program. The constant attention and close cooperation between NASA, White House and Congress are necessary to implement the program of safe and efficient transportation to a number of circumterrestrial orbits. It is to be pointed out that the agency during three months before the end of 2016 did not yet know the budget for 2017. Indeterminacy with the budget increases the problem of managing already compiled programs.

NASA introduces also Exploration Systems Development (ESD). ESD continues to strive for the progress in all three programs: "Orion", systems of launching spaceships (SLS), ground systems, developments and operation (GSDO). During last year it had been achieved the following: the completion of testing analyzer of a series for RS-25 engine in the Stennis Space Centre, the testing of hard fuel rocket engine, the modernization of mobile starting installation for processing a new module, the implementation of «Mission-1», the implementation of structural testing of the crew module in the Glenn Research centre and the arrival of the structural testing program for the module of the European service for "Orion» at the testing stand Plum Brook NASA. As in ESD close ties are designated between designing and developing software, specialists believe that all three programs are working successfully. SLS had completed its critical designing survey; «Orion» and GSDO at present undergo these stages. 
Figure 3

Annual budget request of USA President concerning CCP and its execution (m/n. dol.)

(https://www.nasa.gov/sites/default/files/atoms/files/asap_2015_annual_report.pdf)

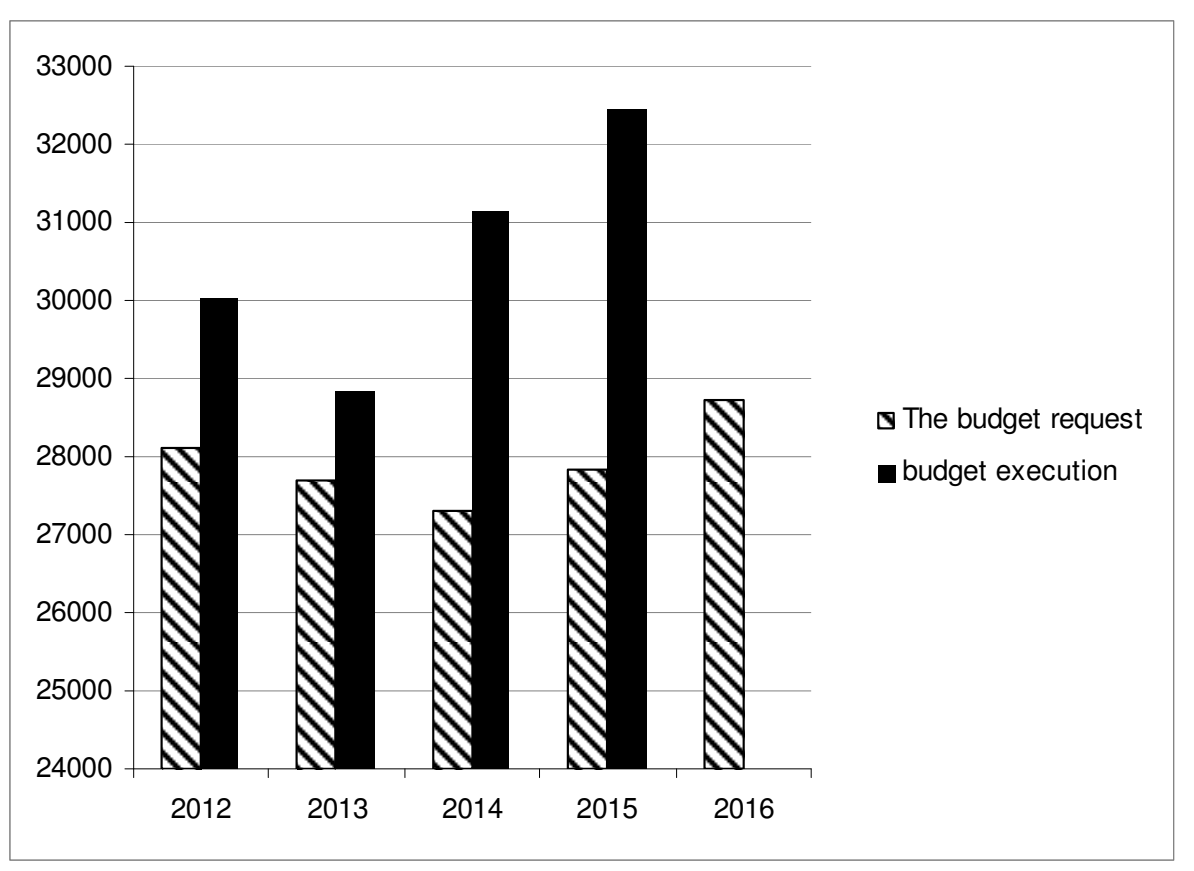

The financing of ESD is presented analogically in fig.4. ESD had been financed at the larger level as compared with the Budget request of President, on the average, by $10,5 \%$ during 2012-2015. However, the financing had been practically similar. Such distribution of resources reflects the program of implementing demands but not the budget built for achieving high results. Besides, the financing planned for separate elements but not for the program in general, which restricts the possibility of NASA to more efficiently distribute resources for solving questions of large scale. As specialists point out, NASA has to introduce the efficient investment strategy. This strategy develops using many new technologies and methodology necessary for future, but does not guarantee integrated potential. At the same time insufficient financing negatively influences the total productivity and safety for a long-term perspective. 
Figure 4

Request for budgeting and real provision for the System of NASA research (mln.dol.)

(https://www.nasa.gov/sites/default/files/atoms/files/asap_2015_annual_report.pdf)

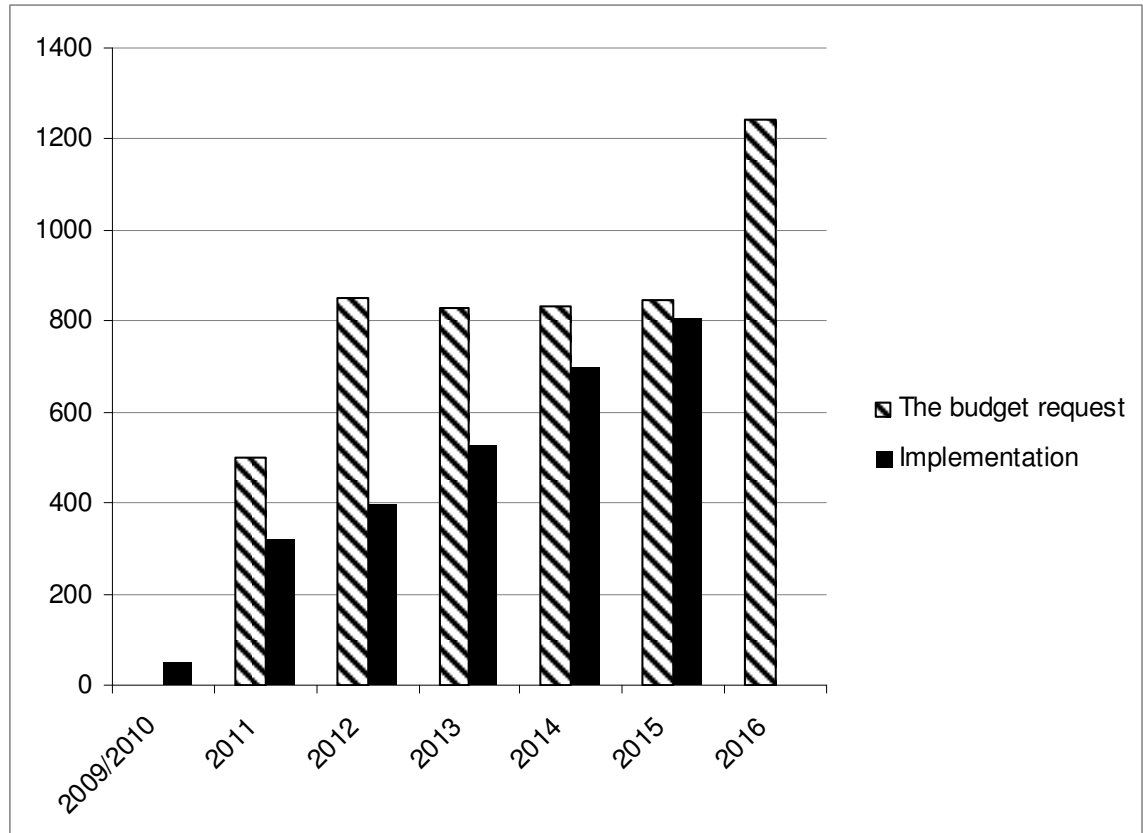

\subsection{Restoration of aerocosmic branch of Ukraine and integration onto European Atlantic space}

A leading Ukrainian enterprise of the cosmic branch of Ukraine is the Pivdenny machine building plant, that is, the State enterprise «Production association named after O.M. Makarov» in the town of Dnipro. The enterprise at present endures not the best times in connection with the under-financing of cosmic programs and, as the aftermath, the conversion of military production. The enterprise manufactures the most ecological in the world rockets- carriers. They are used in transporting commercial loads within the frameworks of international project «Sea start». 
Twenty five years ago Pivdenmash had already undergone hard upheavals: then at once Pivdenmash and together with it the whole branch had been deprived of the state demand on the main production of the enterprise - intercontinental ballistic rockets. Before the enterprise a problem arose of survival and a way-out was found. The main type of production became cosmic rockets-carriers. The depth of conversion surpassed $80 \%$ of the production volume. Unfortunately, times of non-payment and wholesale barter did not pass for the enterprise without marks: during ten years the number of workers decreased four times: from sixty to fifteen thousand persons. The manufacture had drastically reduced of tractors, the production of consumer goods stopped (http://www.yuzhmash.com/ presscenter/news $/$ new?id=265 ).

At the same time Pivdenmash has found its niche at the market of rocket machinery. The manufacture had been arranged of rockets-carriers "Zenith» for the project «Sea start» and "Land start», the conversion program : Dnipro» was acting concerning the use of removed from combat duty intercontinental ballistic rockets for launching into space commercial satellites of various designation, cooperation was waging with American (Orbital ATK _ PH «Antares») and European (AVIO, Italy - $\mathrm{PH}$ «Vega») companies, ambitious Ukrainian-Brazilian project «Cyclone-4» was being put into practice. Besides, the enterprise had been developing episodically cosmic apparatuses.

Till 2012 the enterprise had been working stable though it had been in 2009 that approved by the Government the state Program of developing Pivdenmash and DB «Pivdenne» officially registered the emergence of the crisis and determined main problems and tasks of the association: technical reconstruction, commercialization, optimization of assets, staff. Unfortunately, the program had not yet been implemented. The envisaged financing had not been obtained by any enterprise. Even commercialization which is not in need of budget costs but is vitally necessary for optimizing assets and attracting investments is still being put off.

Starting from the middle of 2012 orders for manufacturing «Zenith» were being curtailed. The reason for this had been understandable: consequences of world economic crisis of 2008. In January 2013 there had been the emergency launch of «Zenith» from the waters of the Pacific Ocean within the framework of the program "Sea start» and since then launches stopped. The clarity in the future of the program appeared only at the end 2016 after the future owner of assets of the complex «Sea start» had been specified (S7 Group) who announced his plans concerning the restoration of launching activity at the complex «Sea start» since 2018.

In summer 2013 because of the constant postponement of terms and repeated significant increased demand for financing the Ministry of defence curtailed the project for developing OTRC «Sapsan». The wholesale breakdown of economic ties with Russia in 2014 resulted in terminating the program «Ground 
start» where "Zenith» was also used. Thus, Pivdenmash during more than two years remained without the market for selling its main production - rocketcarriers «Zenith».

Besides, in October 2014 the explosion after some seconds from the start of a rocket-carrier «Antares» for more than a year and a half stopped the manufacture of the construction of the first stage of the rocket at Pivdenmash. At last in summer 2015 Brazil withdrew from the project «Cyclone-4». This threatened the fate of the project and for the plant it meant the prospect of losing the manufacture of carrier-rockets in general.

As a result of the influence of all these objective factors the curtailment became of incomes, of money costs which during a number of years dropped from 3,4 billion up to 0,8 billion hrn., that is, by more than four times. The situation turned out which may be compared with testing from the situation at the beginning of the 1990s with the only difference that the enterprise had already had no reserve of the then stability: modern equipment, substantial store of raw materials, excess of personnel and loyal partners in cooperation.

The work concerning the guaranteeing of the enterprise loading is carried out in such directions:

1. The broadening of cooperation with manufacturers of leading cosmic states - the USA and the European Union. Dnipro had been visited by NASA representatives who remained satisfied by the enterprise potential. A number of meetings had taken place also in the USA. At the beginning of this year the company "Orbita» won the tender of NASA resulting in the restoration of the manufacture of constructions of the first stage of CR Antares. During a year some shipments of production had been carried out in the programs "Antares» and «Vega».

2. The appearance into new markets. In this direction Pivdenmash is also advancing. Contracts have already been drawn or are in the process of being agreed on with India, Southern Korea, and other perspective partners. Perspectives are new liquid engines developed by DB «Pivdenne». The emergence of really new developments - is what Pivdenmash was waiting for during many years. Therefore, the enterprise takes part in their development, even if contracts are concluded with near to zero return for it. Here developments are impossible without DB «Pivdenne».

3. The output of the production of defence designation. Unfortunately, proposals concerning the production of infantry weapons, module barracks, unpiloted aircrafts and super light planes have not yet been transformed into contracts. Business-plan for organizing the production of cartridges was ignored notwithstanding the already existing deficit of armaments in the country. There remains the manufacture of rocket weapons. Here the situation is more helpful, but only in perspective. The project «Grim-2» is implemented for a foreign cus- 
tomer, and project «Sapsan» in the interests of the Ministry of defence is planned for not earlier than 2019.

Nevertheless, the situation in which the enterprise is at present is still difficult. Today it is possible with certainty to say that the bottom of crisis is overcome. In 2016 the capacity utilization of the enterprise increased by half as much, and already in 2017 the increase will be larger than twice as much which is confirmed already by signed contracts. The strategic perspective of Pivdenmash and cosmic branch in general - is to integrate into foreign markets and earn there. It is to be recognized that now the state is unable to be a main consumer of RCT.

In fact, the hopeful perspective for the enterprise - is to become a part of one of the leading world producers. For this there are certain prerequisites. Present-day long-term tendency for increasing volumes of launching services means the interest of branch leaders in broadening production capacities. The reputation of Pivdenmash and DB «Pivdenne» and the available joint set of competences make them the objects of investment interest in this relation. The creation of the holding as one of the ways of reorganization gives the possibility to make order in organizing Ukrainian cooperation, setting for the foremost place the successful completion of cosmic projects.

It is to be pointed out the pluses of such an approach. The country will preserve the valuable productive stuff and also the possibility of present-day production of modern weapons including non-nuclear means of containment.

The mobilization of a strategic investor will give the possibility not using budget costs to have in Ukraine one of the most science absorbing productions with extremely high added value which guarantees also the channel for borrowing advanced technologies in rocket building.

The strength and competitive advantage of Pivdenmash lies just in the availability of the complete cycle of production. In the close cooperation of developers and manufacturers is revealed the main competitive advantage of DB "Pivdenne» and Pivdenmash as the unified industrial highly technological complex. Both DB and the plant had been created as unified whole oriented at the output of serial production as a final result.

Unfortunately, the state during more than three years had taken the waiting-observing position refusing, in essence, the efficient support for the enterprise. Only in 2016 there were taken some measures of normative and organizational character which gave the possibility to significantly reduce debts in wages and also to completely extinguish debts accumulated for energy sources. 


\section{Conclusions}

A characteristic feature of the present-day development of the world market of weapons and military machinery is that potential importers begin to carry out more demanding policy in this sphere. In contrast to «usual» trade by the production of civil manufacturers in the world trade by weapons and military technical cooperation of many countries there are combined a great number of aspects of international and internal state issues. The trade by weapons is an important instrument of foreign policy which contributes to advancing interests of countries-exporters all over the world and correspondingly influences the political course of countries-importers.

The production and sale of weapons became one of important sources for adding to the budget of developed countries-exporters of weapons. It is expected that in future the production and sale of weapons will more increase about which the appearance is witnessed of new countries which not long ago entered the market of weapons. The main peculiarity of recent years - is the tendency for leaving behind the volumes of export/import of weapons and military machinery as compared with the growing expenditures for the modernization and purchase of weapons and military machinery produced by world weapon industrial complex to meet demands. If the greater part of the world export of weapons is concentrated in still more narrower group of countries, then the main tendency of world import of weapons is the substantial widening of countries-importers of weapons and military machinery with rather great volumes of importing weapons. Hence, the world export and import of weapons and military machinery have opposite tendencies of development from the point of view of the number of countriesparticipants at this market. Ukraine exports such types of defence production: military sea equipment and weapons, armoured equipment and weapons, rocketcosmic and aviation equipment, rocket artillery weapons, armaments, engineering equipment, communication means, anti-aircraft defence measures, and weapons for special subdivisions. Besides this, a substantial component of the military export of Ukraine are the remnants of samples of weapons and military machinery from the store of the Ministry of defence, services in repairing and modernizing military machinery, joint scientific research and design projects.

Substantiated theoretical aspects and applied problems of competitive positions of leading participants at the world market of aerocosmic branch will be used in the further studies to develop strategies of developing the defence potential of Ukraine on account of the development of aerocosmic branch and the economical substantiation of separate measures concerning the holding of competitive positions of leading enterprises of Ukraine at the market of military production. 


\section{References}

1. Orlova, T. S., Konyukhovskyi, E. P. (2011). Transformation of the factors of economic growth in conditions of global economy. Bulletin of Chelyabinsk State University, №36 (251), pp. 39-45 (in Russian).

2. Popovych, O. S., Velentejchyk, T. M. (2010). On the policy of priorities in the sphere of scientific, technological and innovative development. Science and science studies. № 1, pp.13-27 (in Ukrainian).

3. Dehtyarev, A. V. (2013). Actual issues of the aero-space branch in Ukraine. Cosmic science and technology. V. 19.2 (81). pp. 43-51 (in Ukrainian).

4. Horbulin, V. P., Shekhovtsov, V. S., Shevtsov, A. I. (2015). DIC entry of Ukraine into the European defensive and industrial space. Strategic priorities (1) 34, pp. 5-10 (in Ukrainain).

5. Sazonets, I. L. (2016). The impact of government policy of high-tech development on the national and military security of Ukraine. Bulletin of the National University of Water Economy and Environmental Management. Economics, №1, pp. 120-126 (in Ukrainian).

6. Khanin, I. H., Sazonets, I. L. (2015). Directions of enterprises development of defensive and industrial complex of Ukraine in new geopolitical conditions. Efficient economy. №9. Retrieved from: http://www.economy.nayka.com.ua/ (in Ukrainian).

7. Kharuk, A. I. (2009). Design and manufacture of fighter aircraft in Ukraine (1916-1941). Retrieved from: http://www.nbuv.gov.ua/old_jrn/soc_gum/ vnv/2009_12/153-164.pdf.

8. Kharuk, A., Kondratjev, V., Khairulin. M. (2008). «Anatra»: Odessa Aircraft Company, 1910-1924. Tempora, p. 80 (in Ukrainian).

9. Kamjanetska, O.V. (2015). Prospects of development of export potential arms market in Ukraine. «Young scientist». № 6 (21). pp. 8-12 (in Ukrainian).

10. SIPRI Yearbook, (2015). Armaments, Disarmament and International Security. Retrieved from: http://razumkov.org.ua/ua/novyny-tsentru/prezentatsiiashchorichnyka-sipri-2015-ozbroiennia-rozzbroiennia-ta-mizhnarodna- (in Ukrainian).

11. What and whom do the main weapon exporters sell? Retrieved from: http://www.aif.ru/infographic/1137465 (in Russian).

12. The arms race: the fifth generation fighter aircraft. Retrieved from: http://infosvit.org.ua/2013/07/honka-ozbrojen-litaky-vynyschuvachi-pyatohopokolinnya/ (in Ukrainian). 
13. Military industrial complex. Retrieved from: http://www.gumer.info/bibliotek Buks/Econom/world_econom/20.php (In Russian).

14. Fighter aircraft of Generation VI: tomorrow for Russia and the United States. Retrieved from: http://army-news.ru/2016/07/istrebitel-6-pokoleniya-zavtradlya-rossii-i-ssha/ (In Russian).

15. The United States of America have presented a fighter aircraft of Generation VI Retrieved from: http://blogs.korrespondent.net/blog/users/3223445ameryka-prezentuvala-vynyschuvach-shostoho-pokolinnia/ (In Ukrainian).

16. Kondratjev, V. (2000). Odessa «Frenchmen» in the Russian aviation. Aviamaster, № 5, pp. 8-25 (In Russian).

17. Maslov, M. A. (1998). The most subterranial fighter aircraft. №5, pp. 4-9 (In Russian).

18. Medved, A.N., Holobkov, V.Yu., (1995). Fighter aircraft of planes and land tanks. Aviation and time, № 1, pp. 28-31.

19. Aerospace safety ADVISORY PANEL National Aeronautics and Space Administration Retrieved from: https://www.nasa.gov/sites/default/files/atoms/ files/asap_2015_annual_report.pdf/

20. Wings of future or on prospects of technical re-equipement of Ukrainian military aircraft. Retrieved from: http://na.mil.gov.ua/32104-krila-majbutnogoabo-pro-perspektivi-texnichnogo-pereosnashhennya-ukrayinskoyi-vijskovoyiaviaciyi (in Russian).

21. NASA. Retrived from: https://en.wikipedia.org/wiki/NASA

22. Yuzhmash. What was going on and what is going to happen? Retrieved from: http://www.yuzhmash.com/presscenter/news/new?id=265/ (in Russian). 